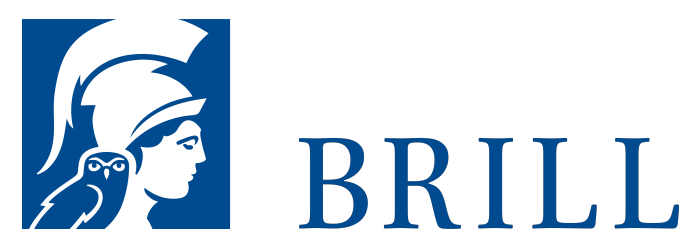

\title{
Les parlers arabes de la région du Mzāb
} (Sahara algérien)

Author: Grand'Henry

Pages: xix, 136

pp. 2

sketchmaps, 1

figure

Language:

French

Subjects:

Literature,

Middle East and

Islamic Studies

Publisher: Brill

Series:

Studies in

Semitic

Languages and

Linguistics,

Volume: 5

E-Book (PDF)

Released online:

27 Mar 2023

ISBN: 978-90-

04-34845-5

List price

USD $\$ 89.00$

Paperback

Publication date: o1 Jun 1976

ISBN: 978-90-

O4-04533-O 
For more information see brill.com

Order information: Order online at brill.com +44330 333 0049 | customerservices@brill.com Submission information: brill.com/authors

Titles published by Brill | Fink, Brill | mentis or Brill | Schöningh: +49(o)715413279216| brill@brocom.de 